\title{
Living Conditions and Illness among Injecting Drug Users in Montreal
}

\section{Bamvita $\mathrm{JM}^{1 *}$, Zunzunegui $\mathrm{MV}^{1}$ and Machouf $\mathrm{N}^{2}$}

${ }^{1}$ Social and Preventive Medicine, Montreal University, Canada

${ }^{2}$ Clinique Médicale l'Actuel, Montreal, Quebec, Canada

\begin{abstract}
Background: The harsh living conditions of injecting drug users (IDUs) are associated with substantial morbidity. Despite the many steps taken to improve the health of IDUs, notably through harm reduction programs, most strategies have focused primarily on proximal risk factors, whereas distal determinants have been poorly addressed.
\end{abstract}

Objectives: This study identifies distal and proximal factors associated with recent episodes of illness among IDUs living in Montreal in 2005.

Methods: A cross-sectional survey was carried out between February and September 2005 in 666 IDUs 18 years old and over, living in Montreal, Quebec.

Results: The living conditions of IDUs illustrate their marginality: $70 \%$ are on social welfare, $38 \%$ beg for a living, $48 \%$ have a history of imprisonment, and $20 \%$ live on the street. Among the study sample, 176 subjects (26\%) reported an episode of illness in the 6 months before the interview. Multiple regression analysis showed that the pathway from socio-demographic conditions to illness in IDUs is mediated by financial strain, marginality, risk behaviors and chronic health conditions. Eight distal factors were associated with episodes of illness in the last 6 months: female gender, older age, bisexual orientation, financial strain (begging on the street, receiving help from community centers), marginality (history of imprisonment or fine for criminal offenses, stealing, having no identity card), heroin injection, combined use of both cocaine and heroin, and sharing injection material. More proximally related factors were HIV infection, HCV infection and depression.

Conclusions: Current IDUs in Montreal live under difficult conditions which have serious health consequences. Efforts to improve their health should focus on changing these conditions.

Keywords: IDUs; Injection drug users; Marginality; Morbidity; Harm reduction strategies; Montreal; Canada

\section{Introduction}

Injection drug behavior constitutes a serious public health problem in the developed world, especially in North America [1-6]. At the end of the last decade in Montreal, Quebec, about 12,000 persons [7] were injecting drugs. Public health concerns related to illegal drug injection include the spread of HIV $[3,8,9]$ and HCV infections [10-12], sexually transmitted diseases [13] and mental health problems [14,15]. In spite of their high morbidity, injection drug users (IDUs) reportedly misuse health services, particularly by overusing hospital emergency rooms [16-23].

The living conditions of IDUs result in an accumulation of health risk factors. In addition to illegal drug abuse, alcohol and cigarette consumption are common [17]. Many IDUs have a history of homelessness [4]. Substance abuse in IDUs constitutes a major determinant of unsafe sexual contacts leading to sexually transmitted diseases [13]. Drug dependency, financial strain and debt may drive them to violence or to trade sex to obtain money or drugs [20,24,25]. Such harsh living conditions may eventually lead to illegal behaviors and multiple imprisonments [26-28]. The social and health problems of IDUs are interwoven with poverty and social exclusion. Phelan et al. [29] have extensively studied the way ill health conditions could impact people's health status, conditions they called "fundamental causes" of social inequalities in health.

A number of health problems are associated with drug use. It has been estimated that 70 to $80 \%$ of IDUs in Montreal may be infected with HCV [10-12]. The estimated prevalence of HIV-infected IDUs amounts to $11 \%$ in Montreal city $[8,30]$. Dual diagnosis of drug addiction and psychiatric problems is frequent. At the end of the last decade, the number of illicit drug users (by injection or any other route) suffering from mental illness in Montreal city ranged from 25,000 to 40,000 [14]. A study carried out in other contexts among drug users reported a high frequency of complications stemming from drug injection, such as soft tissue infections, thrombosis, embolism and septicemia [31]. Illicit drug use is frequently associated with alcohol abuse and cigarette smoking [17], sex trade and traumas from violence $[13,25,32]$. One study has reported an association between overdoses from heroin and suicide attempts [33].

Despite over a decade of intensive harm reduction strategies and the many steps taken to address drug-related health issues, the health status of IDUs is still a cause for concern. In a study carried out in Vancouver, Spittal et al. [34] revealed the high health risk of female IDUs (compared to the female general population of British Columbia) by observing a fifty-fold increase in their mortality rate. Corneil et al. [35] showed an increased risk of HIV infection among Vancouver IDUs who reported living in unstable housing conditions.

*Corresponding author: Jean-Marie Bamvita, MD, M.Sc., Department of Social and Preventive Medicine, University of Montreal, 1227 SaintChristophe, Montreal, Quebec, H2L 3W5, Canada, Tel: 514-792-8281; E-mail: wansuanganbamvita@sympatico.ca

Received November 25, 2013; Accepted December 16, 2013; Published December 18, 2013

Citation: Bamvita JM, Zunzunegui MV, Machouf N (2013) Living Conditions and Illness among Injecting Drug Users in Montreal. Health Care Current Reviews 1: 111. doi: $10.4172 / 2375-4273.1000111$

Copyright: (c) 2013 Bamvita JM, et al. This is an open-access article distributed under the terms of the Creative Commons Attribution License, which permits unrestricted use, distribution, and reproduction in any medium, provided the original author and source are credited. 
This study identifies both proximal and distal factors associated with recent episodes of illness among IDUs. By targeting acute manifestations of illness in IDUs, such as overdoses and soft tissue infections, intervention programs only partly address morbidity issues among this population. First, etiologic research should identify distal determinants of IDUs' morbidity, in order to implement welltailored intervention programs targeting the entire spectrum of IDUs' risk factors for morbidity. By focusing prevention on those distal determinants, or "fundamental causes" according to Phelan et al. [29], health service managers could redirect efforts to integrated care for chronic problems such as alcohol dependency, HIV infection, hepatitis $\mathrm{C}$ and mental health, in tandem with social services devoted to the IDU population.

\section{Methods}

\section{Study population and data collection}

The study population consisted of injecting drug users living in Montreal who were 18 years of age or older. Participants were recruited on the streets of downtown Montreal using a convenient sampling method in which selected participants could refer their IDU friend to the interviewer [36,37]. The interviewer, a former injection drug user, completed a training session before the survey and had easy access to IDUs. To avoid selection bias due to subjective selection of known IDUs, the interviewer was instructed not to contact friends or relations, but simply to inform IDUs about the study and distribute his business cards so that those interested could call to arrange an interview. Each IDU contacted was also asked to invite other known IDUs to participate in the study. The inclusion criteria were: residence in Montreal for at least one year, age 18 years or over and intravenous drug use at least once in the previous 6 months. Participants signed an informed consent form, which contained a numerical code to match with the anonymous questionnaire. Participants were interviewed. The questionnaire was filled in by the interviewer. Most of the interviews took place in our research office. But some interviews were carried out in other offices in the neighborhood of the participants, such community health centers, syringe exchange program centers, etc. Confidentiality and discretion were the conditions required to use an office for the interview. The Research Ethics Board of the University of Montreal approved the study.

On completion of the questionnaire, participants received a payment of CAN\$10 to compensate them for their time. Respondents whom the interviewer judged to require particular services were also given a brief counseling session and referred to a social service. The use of a single interviewer was helpful in preventing people from answering the questionnaire more than once, since he could generally recognize those who had already participated. The study was conducted from February to September 2005.

\section{Measurements}

The dependent variable for this study was the self-reported occurrence of any illness episode in the 6 months before the interview, in response to the questions: "Have you suffered from any illness during the last 6 months? What was your health problem?"

The list of potential explanatory variables was drawn from the literature on the morbidity of IDUs and included sociodemographic variables, economic conditions, marginality, risk behaviors and health status, according to the schema proposed by Estébanez et al. [38]. Socio-demographic characteristics (gender, age, education and sexual orientation) may have a direct or indirect impact (through marginality and risk behaviors) on the occurrence of episodes of illness. Sexual orientation included three categories: homosexuals, heterosexuals and bisexuals. Employment, type of housing and obvious indicators of financial strain, such as receiving regular help from a community center (i.e. clothing, food or furniture) and begging on the street, were used as a measure of economic condition. Combining the latter two factors (receiving help and begging) yielded the variable "number of indicators of financial strain". Employment status consisted of three categories: full time job, other jobs (part time job, independent job, occasional jobs), and welfare.

Marginality may act directly or indirectly through risk behaviors, on the occurrence of an episode of illness. The marginality indicators included: sex trade, fines for criminal offenses, previous imprisonment, unemployment and homelessness. Living arrangements consisted of three categories: independent living arrangements (rented apartment or house), dependent living arrangements (family house, friend's house, public shelter for homeless people), and homelessness (living on the street or in abandoned houses). The variable "number of marginality indicators" was created by combining history of imprisonment, fine for criminal offense, stealing and lack of identity cards.

Risk behaviors were measured for the six months before interview and included alcohol consumption, the type of drug injected the frequency of drug injection and sharing injection materials. Sharing injection materials was defined as giving to one another used materials (syringe, needle, filter, etc.) to inject drugs, in the prior 6 months. The injection drugs considered were mainly heroin, cocaine and their derivatives (crack cocaine, speedball). Two variables having participated in treatment for drug abuse and past or present participation in a needle exchange program - were used to evaluate access to social support, while prior visit to preventive health clinics was the criterion for health services utilization.

The health-related variables were chronic infectious disease (HIV infection, HCV infection) and a history of mental illness. Mental illness was defined as any psychiatric illness diagnosed by a healthcare professional (such as schizophrenia, schizophrenia spectrum disorders, bipolar disorders, mania, major depression, anxiety disorders, etc.), and not merely any self-perceived mental disorder not evaluated by a mental health professional. Depressive symptoms were assessed using a 13-item CES-D (Center for Epidemiologic Studies Depression) scale [39], scored on a scale of 0 to 39 points (i.e., 0 to 3 points per item) with a cut-off at 13 points.

All those potential risk factors for episodes of illness can be divided in two main groups: distal factors (demographic factors, socioeconomic conditions, marginality and risk behavior) and proximal factors (health status and chronic diseases).

\section{Statistical analysis}

Data quality was monitored by checking for possible duplications after listing subjects in an Excel file by name, reported age, birthday, and age calculated from reported birthday. Major discordances or incoherencies (e.g. declared age that did not match age calculated from the birthday), similarities in names or age, were then analyzed using SPSS software. Questionnaires considered to be duplicates based on the foregoing information and a comparison of participants' signatures, were excluded.

Bivariate analyses were performed for each independent variable 
to calculate the potential association with the occurrence of illness in the previous 6 months, and the statistical significance of the relation was assessed using Pearson's $X^{2}$ test. Multiple logistic regression models were fitted using staggered entry of variables according to the previously described schema: sociodemographic factors, economic conditions, marginality, risk behaviors, support and service use, and health status. Within each block, variables were selected by using a stepwise backward strategy in which statistical criteria for entry and retention of variables in each model were $p \leq 0.10$ and $p \leq 0.05$, respectively. Blockwise entry is the best strategy to highlight changes in the values of the coefficients following inclusion of explanatory variables in the model. The log-likelihood statistic and the Chi-square test were used to assess improvement in the model, while the HosmerLemeshow test was used to evaluate its goodness of fit.

\section{Results}

A total of 678 subjects responded to the questionnaire. After completing the data-quality monitoring process, 12 questionnaires were excluded. Further analyses were carried out on the remaining 666 participants. Only $17 \%$ of them had completed more than secondary school (college or university); $12 \%$ had a full time job, while $70 \%$ were receiving social welfare benefits. Six percent had no identity card, $38 \%$ begged on the street, $48 \%$ had a history of imprisonment, $49 \%$ reported receiving help from a community center on a regular basis, and $20 \%$ were living strictly on the street.

Within the whole sample, 176 subjects (26\%) reported an episode of illness in the previous 6 months. These episodes included drug overdoses and abscess at the site of injection; acute infections such as pneumonia, influenza, and gastroenteritis; mental illness and suicide attempts; traumas from violence; and fatigue \& indigestion and herpes \& sepsis. Overall, 140 participants reported 1 episode, 31 reported 2 episodes and 5 reported 3 episodes.

Tables 1-3 show the distribution of the sample according to the selected risk factors for episodes of illness. Overall, 36\% of females versus $25 \%$ of males had some illness in the 6-month recall period. Older IDUs and bisexuals were more likely to report illness episodes than younger IDUs and heterosexuals or homosexuals (Table 1). Indicators of financial strain (begging on the street, receiving help in community centers) are associated with episodes of illness. Homeless IDUs were more likely to report episodes of illness than those living in the home of friends or family, or than those who lived in their own house or apartment (respectively, $34 \%, 28 \%$ and $24 \% ; \mathrm{P}=0.093$ ).

All the marginality indicators were related to the frequency of episodes of illness: IDUs involved in sex trade (42\% versus 24\%; $\mathrm{P}<0.001$ ), and those with a history of imprisonment ( $34 \%$ versus $21 \%$; $\mathrm{P}<0.001$ ) (Table 3 ). The type of drug consumed and the frequency of drug injection were associated with episodes of illness. Those who injected both heroin and cocaine reported more episodes than those who injected only heroin or cocaine $37 \%, 31 \%$ and $23 \%$, respectively; $\mathrm{P}=0.007)$. IDUs who injected drugs more than once a day were more likely to have an episode of illness than those reporting a lower frequency of injection ( $33 \%$ versus $21 \%$; $\mathrm{P}<0.001)$. Sharing injection materials was also associated with a higher frequency of illness $(45 \%$ versus $23 \% ; \mathrm{P}<0.001)$.

\begin{tabular}{|c|c|c|c|c|c|}
\hline \multirow{2}{*}{\begin{tabular}{|l|} 
Independent variables \\
Socio-demographic factors \\
\end{tabular}} & \multirow[t]{2}{*}{ Categories } & \multirow[t]{2}{*}{$\mathrm{N}=666$} & \multicolumn{2}{|c|}{$\begin{array}{l}\text { Episodes of illness } \\
(\mathrm{N}=176=26,4 \%)\end{array}$} & \multirow[t]{2}{*}{ P value } \\
\hline & & & $\begin{array}{l}\text { Yes (N: 176) } \\
(\%)\end{array}$ & $\begin{array}{l}\text { No }(\mathrm{N}: 481) \\
(\%)\end{array}$ & \\
\hline \multirow[t]{2}{*}{ Gender } & Male & 556 & $136(24.5)$ & $420(75,5)$ & \multirow[t]{2}{*}{0.010} \\
\hline & Female & 110 & $40(36.4)$ & $70(63.6)$ & \\
\hline \multirow[t]{3}{*}{ Age (years) } & $<30$ & 348 & $79(22.7)$ & $269(77.3)$ & \multirow[t]{3}{*}{$<0.001$} \\
\hline & $30-39$ & 169 & $35(20.7)$ & $134(79.3)$ & \\
\hline & $\geq 40$ & 147 & $62(42.2)$ & $85(57.8)$ & \\
\hline \multirow[t]{2}{*}{ Education } & $\leq$ Secondary & 548 & $143(26.1)$ & $405(73.9)$ & \multirow[t]{2}{*}{0.729} \\
\hline & >Secondary & 112 & $31(27.7)$ & $81(72.3)$ & \\
\hline \multirow[t]{3}{*}{ Sexual orientation } & Heterosexual & 556 & $134(24.1)$ & $422(75.9)$ & \multirow[t]{3}{*}{0.007} \\
\hline & Homosexual & 42 & $12(28.6)$ & $30(71.4)$ & \\
\hline & Bisexual & 61 & $26(42.6)$ & $35(57.4)$ & \\
\hline \multicolumn{6}{|l|}{ Economic conditions } \\
\hline \multirow[t]{3}{*}{ Employment } & Full time job & 73 & $19(26.0)$ & $54(74.0)$ & \multirow[t]{3}{*}{0.150} \\
\hline & $\begin{array}{l}\text { Other jobs (part time job, independent job, occasional } \\
\text { jobs) }\end{array}$ & 116 & $22(19.0)$ & $94(81.0)$ & \\
\hline & Social welfare & 430 & $120(27.9)$ & $310(72.1)$ & \\
\hline \multirow[t]{3}{*}{ Housing } & $\begin{array}{l}\text { Independent living arrangements (own/rented } \\
\text { apartment or house) }\end{array}$ & 310 & $73(23.5)$ & $237(76.5)$ & \multirow[t]{3}{*}{0.093} \\
\hline & $\begin{array}{l}\text { Dependent living arrangements (family house, } \\
\text { friend's house, public shelter) }\end{array}$ & 210 & $58(27.6)$ & $152(72.4)$ & \\
\hline & $\begin{array}{l}\text { Homelessness (living on the street or in abandoned } \\
\text { houses) }\end{array}$ & 128 & $43(33.6)$ & $85(66.4)$ & \\
\hline \multirow{2}{*}{$\begin{array}{l}\text { Receiving help from } \\
\text { a community center }\end{array}$} & Yes & 314 & $120(38.2)$ & $194(61.8)$ & \multirow[t]{2}{*}{$<0.001$} \\
\hline & No & 325 & $52(16.0)$ & $273(84.0)$ & \\
\hline \multirow[t]{2}{*}{ Begging on the street } & Yes & 253 & $83(32.8)$ & $170(67.2)$ & \multirow[t]{2}{*}{0.003} \\
\hline & No & 412 & $92(22.3)$ & $320(77.7)$ & \\
\hline \multirow{3}{*}{$\begin{array}{l}\text { Number of indicators of financial strain (begging on the street, } \\
\text { receiving help in community centers) }\end{array}$} & 0 & 269 & $64(23.9)$ & $205(76.2)$ & \multirow[t]{3}{*}{$<0.001$} \\
\hline & 1 & 181 & $60(33.0)$ & $121(66.8)$ & \\
\hline & 2 & 188 & $57(40.3)$ & $131(70.0)$ & \\
\hline
\end{tabular}

Table 1: Episodes of illness in last 6 months among IDUs in Montreal, by socio-demographic factors and economic conditions. 
Citation: Bamvita JM, Zunzunegui MV, Machouf N (2013) Living Conditions and Illness among Injecting Drug Users in Montreal. Health Care Current Reviews 1: 111. doi: 10.4172/2375-4273.1000111

Page 4 of 7

\section{Drug overdoses}

Pneumonia

influenza

Abscess at the site of injection

Gastroenteritis

Mental crisis

Trauma

Fatigue \& indigestion

Herpes, sepsis

Suicide attempts

Others (migraine, dental abscess, alcohol intoxication, endocarditis, unspecified abdominal ache, bone ache, fever, diarrhoea)

Table 2: Episodes of acute illnesses reported for the prior 6 months in participants $(\mathrm{N}=176)$.

\begin{tabular}{|c|c|c|c|c|c|}
\hline \multirow{2}{*}{\begin{tabular}{|l|} 
Independent variables \\
Marginality
\end{tabular}} & \multirow[t]{2}{*}{ Categories } & \multirow[t]{2}{*}{$N=666$} & \multicolumn{2}{|c|}{ Episodes of illness $(\mathrm{N}=176=26.4 \%)$} & \multirow[t]{2}{*}{$P$ value } \\
\hline & & & Yes (N: 176) (\%) & No (N: 481) (\%) & \\
\hline \multirow{2}{*}{ Sex trade } & Yes & 89 & $37(41.6)$ & $52(58.4)$ & \multirow{2}{*}{$<0.001$} \\
\hline & No & 576 & $138(24.0)$ & $438(76.0)$ & \\
\hline \multirow{2}{*}{ Fine for criminal offense } & Yes & 344 & $126(36.6)$ & $218(63.4)$ & \multirow{2}{*}{$<0.001$} \\
\hline & No & 285 & $45(15.8)$ & $240(84.2)$ & \\
\hline \multirow{2}{*}{ Previous imprisonment } & Yes & 300 & $103(34.3)$ & $197(65.7)$ & \multirow{2}{*}{$<0.001$} \\
\hline & No & 332 & $68(20.5)$ & $264(79.5)$ & \\
\hline \multirow{4}{*}{$\begin{array}{l}\text { Number of marginality indicators (imprisonment, fine for criminal offense, stealing, no } \\
\text { identity card) }\end{array}$} & 0 & 225 & $48(18.8)$ & $177(78.7)$ & \multirow{4}{*}{$<0.001$} \\
\hline & 1 & 97 & $14(14.8)$ & $83(85.6)$ & \\
\hline & 2 & 220 & $99(44.9)$ & $121(55.0)$ & \\
\hline & 3 & 65 & $11(16.5)$ & $54(83.1)$ & \\
\hline \multicolumn{6}{|l|}{ Risk behaviors } \\
\hline \multirow{2}{*}{ Alcohol consumption } & $\leq 2$ drinks/day & 254 & $56(22.0)$ & $198(78.0)$ & \multirow{2}{*}{0.091} \\
\hline & $\geq 3$ drinks/day & 315 & $89(28.3)$ & $226(71.7)$ & \\
\hline \multirow{3}{*}{ Drug injected } & Heroin only & 77 & $24(31.2)$ & $53(68.8)$ & \multirow{3}{*}{0.007} \\
\hline & Heroin + cocaine & 108 & $40(37.0)$ & $68(63.0)$ & \\
\hline & Cocaine only & 476 & $110(23.1)$ & 366 (76.9) & \\
\hline \multirow{2}{*}{ Frequency of drug injection } & $>$ Once/day & 291 & $97(33.3)$ & $194(66.7)$ & \multirow{2}{*}{$<0.001$} \\
\hline & $\leq$ Once/day & 368 & $76(20.7)$ & $292(79.3)$ & \\
\hline \multirow{2}{*}{ Sharing injection materials } & Yes & 104 & $47(45.2)$ & $57(54.8)$ & \multirow{2}{*}{$<0.001$} \\
\hline & No & 542 & $124(22.9)$ & $418(77.1)$ & \\
\hline
\end{tabular}

Table 3: Episodes of illness in last 6 months among IDUs in Montreal, by factors of marginality and risk behaviors

\begin{tabular}{|c|c|}
\hline Frequency & Percent \\
\hline 28 & 15,9 \\
\hline 20 & 11,4 \\
\hline 20 & 11,4 \\
\hline 16 & 9,1 \\
\hline 12 & 6,8 \\
\hline 10 & 5,7 \\
\hline 10 & 5,7 \\
\hline 8 & 4,5 \\
\hline 5 & 2,8 \\
\hline 5 & 2,8 \\
\hline 42 & 23,9 \\
\hline
\end{tabular}

\begin{tabular}{|c|c|c|c|c|c|}
\hline \multirow{2}{*}{\begin{tabular}{|l|} 
Independent variables \\
Social support and services
\end{tabular}} & \multirow[t]{2}{*}{ Categories } & \multirow[t]{2}{*}{$N=666$} & \multicolumn{2}{|c|}{ Episodes of illness $(\mathrm{N}=176=26.4 \%)$} & \multirow[t]{2}{*}{$P$ value } \\
\hline & & & Yes (N: 176) (\%) & No (N: 481) (\%) & \\
\hline \multirow{2}{*}{$\begin{array}{l}\text { Any treatment } \\
\text { for drug abuse }\end{array}$} & Yes & 259 & $97(37.5)$ & $162(62.5)$ & \multirow[t]{2}{*}{$<0.001$} \\
\hline & No & 345 & $49(14.2)$ & $296(85.8)$ & \\
\hline \multirow{2}{*}{$\begin{array}{l}\text { Having visited } \\
\text { a preventive health } \\
\text { service in the past }\end{array}$} & Yes & 491 & $142(28.9)$ & $349(71.1)$ & \multirow[t]{2}{*}{0.013} \\
\hline & No & 172 & $33(19.2)$ & $139(80.8)$ & \\
\hline \multirow{2}{*}{$\begin{array}{l}\text { Enrolled in a needle } \\
\text { exchange program }\end{array}$} & Yes & 466 & $139(29.8)$ & $327(70.2)$ & \multirow[t]{2}{*}{0.001} \\
\hline & No & 193 & $34(17.6)$ & $159(82.4)$ & \\
\hline \multicolumn{6}{|l|}{ Health status } \\
\hline \multirow{2}{*}{ HIV infection } & Yes & 56 & $29(51.8)$ & $27(48.2)$ & \multirow[t]{2}{*}{$<0.001$} \\
\hline & No & 610 & $147(24.1)$ & $463(75.9)$ & \\
\hline \multirow[t]{2}{*}{ HCV infection } & Yes & 125 & $57(45.6)$ & $68(54.4)$ & \multirow[t]{2}{*}{$<0.001$} \\
\hline & No & 541 & $119(22.0)$ & $422(78.0)$ & \\
\hline \multirow{2}{*}{ Mental illness } & Yes & 78 & $36(46.2)$ & $42(53.8)$ & \multirow[t]{2}{*}{$<0.001$} \\
\hline & No & 588 & $140(23.8)$ & $448(76.2)$ & \\
\hline \multirow[t]{2}{*}{ Depression score (CES-D) } & <13: no depression & 158 & $19(12.0)$ & $139(88.0)$ & \multirow[t]{2}{*}{$<0.001$} \\
\hline & $\geq 13$ : depression & 456 & $127(27.9)$ & $329(72.1)$ & \\
\hline
\end{tabular}

Table 4: Episodes of illness in last 6 months among IDUs in Montreal, by social support and health status factors. 
IDUs using community services were more likely to report illness in the previous 6 months (Table 4). In particular, those with a history of drug abuse treatment, those receiving help from community centers and those who had used preventive services in the past for STD testing, hepatitis testing, vaccination or needle exchange had more illness episodes than those who had not used these services. Chronic infections with HIV and HCV, mental illness and current high depressive symptoms were also associated with higher frequency of illness episodes in the 6 previous months.

The estimated odds ratios using multivariate analysis are shown in Table 5. Gender and age were significantly associated with the probability of episodes of illness even after adjusting for all other risk factors, and their coefficients remained stable throughout the five models. Female IDUs had a two-fold increased risk of illness compared to male IDUs. Older IDUs were more likely to have an illness than younger IDUs. Homosexuals had $60 \%$ more risk of illness than heterosexuals. This association was not significant, except after adjusting for marginality. Conversely, the likelihood of illness in bisexuals was stable up to the final model and consistently remained twice as high as in heterosexuals. Financial strain and marginality were also independently associated with illness, and had stable coefficients. Persons who injected heroin had a two-fold increase in the risk of illness compared to those who injected cocaine only. Those who injected both cocaine and heroin had the highest odds of illness compared with those who injected just one of these drugs. Sharing injection materials was associated with a two-fold increase in the risk of illness. In the final model, three chronic conditions were associated with the occurrence of illness: HIV infection, HCV infection and mental illness. As shown by the ascending values of the Chi-square test and the descending values of the log-likelihood statistic, the final model improved progressively as covariates were added to the equations.

\section{Discussion}

The purpose of this study among Montreal IDUs in 2005, 20 years after the rapid spread of HIV among IDUs in North America, was to identify distal and proximal factors associated with recent episodes of illness. These IDUs, whose mean age was 31 years $( \pm 10)$, and who had been using injection drugs for an average of 9.52 years $( \pm 7.47)$, constitute a cohort of people who have managed to survive amidst the HIV epidemic.

This study aimed to increase our understanding of the fundamental causes of IDUs' ill health in spite of many years of harm reduction programs. The results can be summarized as three principal findings. First, financial strain and marginality are associated with recent episodes of illness. Second, risk injecting behaviors continue to be highly prevalent and, as expected, are associated with recent episodes of illness. Third, mental illness, HIV and HCV infections are at the core of poor health in IDUs.

Multivariate analyses show the major predictors of recent illness episodes, illustrating mainly that the pathway from socioeconomic conditions to occurrence of illness in IDUs is shaped by financial strain, marginality and risk behaviors, mostly in those whose health status is already weakened by chronic viral infections.

Financial strain seems to be estimated with accuracy by the two variables "begging on the street" and "receiving help from a community center". Indeed, other variables could be considered such as "homelessness" and "having no job". But those variables are weakly associated with disease occurrence $(\mathrm{P}=0.093$ and 0.150 respectively) and do not strongly illustrate the IDUs' situation of misfortune.

Indicators of marginality seem to be well represented by history of imprisonment, fine for criminal offenses, stealing and having no

\begin{tabular}{|c|c|c|c|c|c|}
\hline & Model A & Model B & Model C & Model D & Model E \\
\hline & Socio-demographic factors & Economic conditions & Marginality & Risk behaviors & Health status \\
\hline Variables & OR $(95.0 \%$ IC) & OR $(95.0 \%$ IC) & OR (95.0\% IC) & OR $(95.0 \%$ IC) & OR $(95.0 \%$ IC) \\
\hline Gender & $0.49(0.31-0.79)^{\star *}$ & $0.43(0.26-0.71)^{\star * \star}$ & $0.35(0.21-0.60)^{* * *}$ & $0.43(0.24-0.75)^{\star *}$ & $0.47(0.26-0.84)^{*}$ \\
\hline Age & $1.04(1.02-1.06)^{\star * *}$ & $1.04(1.02-1.05)^{\star * *}$ & $1.03(1.01-1.05)^{* * *}$ & $1.04(1.02-1.06)^{\star * *}$ & $1.03(1.01-1.05)^{*}$ \\
\hline \multicolumn{6}{|l|}{ Sexual orientation } \\
\hline Heterosexuals & 1 & 1 & 1 & 1 & 1 \\
\hline Homosexuals & $1.46(0.72-2.98)$ & $2.12(1.00-4.51)$ & $2.56(1.13-5.81)^{*}$ & $1.86(0.79-4.41)$ & $1.62(0.66-3.97)$ \\
\hline Bisexuals & $2.11(1.19-3.72)^{\star *}$ & $2.08(1.15-3.76)^{*}$ & $2.28(1.22-4.26)^{* *}$ & $2.28(1.15-4.52)^{*}$ & $2.30(1.14-4.61)^{*}$ \\
\hline \multicolumn{2}{|l|}{$\begin{array}{l}\text { Number of indicators } \\
\text { of financial strain }\end{array}$} & $1.80(1.43-2.25)^{\star * *}$ & $1.65(1.28-2.12)^{* * *}$ & $1.61(1.23-2.10)^{\star * *}$ & $1.44(1.09-1.89)^{\star *}$ \\
\hline \multicolumn{2}{|l|}{$\begin{array}{l}\text { Number of indicators } \\
\text { of marginality }\end{array}$} & & $1.39(1.14-1.69)^{* * *}$ & $1.38(1.12-1.71)^{\star *}$ & $1.35(1.09-1.69)^{* *}$ \\
\hline \multicolumn{6}{|l|}{ Drug injected } \\
\hline Cocaine only & & & & 1 & 1 \\
\hline Heroin only & & & & $1.66(0.95-2.92)$ & $1.82(1.02-3.23)^{*}$ \\
\hline Cocaine and heroin & & & & $2.53(1.28-5.01)^{\star *}$ & $2.97(1.48-5.95)^{* *}$ \\
\hline \multicolumn{2}{|l|}{ Sharing injection materials } & & & $2.07(1.23-3.47)^{\star \star}$ & $1.81(1.06-3.10)^{*}$ \\
\hline HIV infection & & & & & $2.03(1.00-4.14)$ \\
\hline HCV infection & & & & & $1.84(1.07-3.15)^{*}$ \\
\hline Mental illness & & & & & $2.09(1.15-3.81)^{*}$ \\
\hline$-2 L L$ & 722.669 & 671.215 & 612.004 & 568.816 & 548.121 \\
\hline Improvement $X^{2}$ & 32.785 & 60.098 & 80.263 & 95.727 & 116.423 \\
\hline Hosmer-Lemeshow test ( $\mathrm{P}$ value) & 0,532 & 0,987 & 0,113 & 0,195 & 0,162 \\
\hline
\end{tabular}

${ }^{*} \mathrm{P}<0.05$

aBegging, receiving help in community centers

bImprisonment, fine, stealing, no identity card

Table 5: Odds ratios for factors associated with episodes of illness in last 6 months among IDUs in Montreal. 
identity card. We considered including sex trade with these factors but this was rejected in the multivariate model using backward regression, because its association with disease occurrence is mediated by other factors of marginality.

The association between heroin injection and illness was not significant but became stronger once chronic diseases were considered. Among those who injected both heroin and cocaine, the association was even stronger and increased in magnitude when chronic diseases were taken into account. This observation illustrates the synergistic effect between drug abuse and ill health, as shown in the fact that drug abuse is more detrimental in IDUs whose health status is already compromised.

Our findings are similar in some respects to those of other studies in IDU populations. The participants were predominantly male, as has been seen in many other studies [17,20,40-42]. Female IDUs seemed more likely to be ill than male IDUs, as has also been shown by Chitwood et al. [43]. Bisexual IDUs seemed to be at higher risk than heterosexual IDUs. Boulton et al. reported that, while homosexual men are more likely to have protected sexual contact with their male partners, bisexual men usually engage in protected sex with men and unprotected sex with female partners [44]. In our study, the odds ratio for illness in bisexuals was significant in the first (OR: 2.11 (1.19-3.72) and all subsequent models, suggesting that unprotected sex may also be an explanatory factor.

Other studies have reported the link between financial strain and high morbidity $[5,42]$. In bivariate analyses, access to needle exchange programs has been associated with increased morbidity [45], a finding that may be explained by the attraction of needle exchange programs to IDUs at higher risk of HIV infection.

Selection and measurement biases may have gone undetected in our study. Selection biases could have resulted from the non-probabilistic nature of the design, yielding an unpredictable direction in the associations. In addition, self-reported illness and risk behaviors could have been influenced by social desirability, which would have reduced the magnitude of the associations. Nevertheless, previous studies have already confirmed the reliability of self-reported data in IDUs [46-49]. Subjects suffering from acute illnesses could have reported their risk factors with more precision than those who were feeling healthy at the time of the interview, a situation that could have led to a recall bias with an association towards the null. Confounding factors such as violence and lifelong victimization were not collected, although the episodes of illness related to violence were high for a 6 -month recall period $(10 \%$ of episodes). Like any cross-sectional survey, this study, along with the statistical inferences yielded by analyses, should be interpreted cautiously. As far as we know, this is the first population based study of IDUs in the city of Montreal. All previous studies have been based on clinic and social service attendees $[3,8,12,36,44]$. The findings of this study contribute to our knowledge of the relation between living conditions and morbidity among these survivors of the HIV epidemic.

\section{Conclusions}

Many harm reduction strategies have been implemented during the last decade [50-52]. Efforts have been made to help IDUs reduce risk-taking behaviors as regards safe injection practices and safe sex [53-57]. Integrated programs focused on harm reduction strategies in connection with primary care and drug abuse treatment have been proposed [42]
This study highlights the relevance of taking a broad perspective when studying determinants of morbidity in IDUs. From our analyses and other studies, there is strong evidence suggesting that the high rate of morbidity in IDUs is due to social exclusion and their extremely harsh living conditions. A better organization of primary health care would result in even greater utilization of health services unless measures are taken at the social baseline to improve the living conditions of IDUs, notably for street-entrenched, runaway and unemployed IDUs [57]. In addition, Gunn et al. [50] have proposed meaningful solutions related with harm reduction strategies, notably through improvement of access to the primary health care system. Health improvement programs should prolong downwards to the social ground where the IDU population lives, encompassing living arrangements, mental rehabilitation and occupational therapy. The harm reduction strategies proposed by Palepu et al. [42] should be considered as well. Health needs in IDUs are complex and should be addressed primarily at a more remote step, in the community, providing integrated care according to their individual conditions with the implication of outreach workers, social workers and nurses who have close ties with IDUs.

\section{Acknowledgements}

The authors thank the following organizations for their financial support in carrying out this study: GIRU, GREAS, GRIS and FRSQ.

\section{References}

1. Aceijas C, Stimson GV, Hickman M, Rhodes T (2004) United Nations Reference Group on HIVIAIDS Prevention and Care among IDU in Developing and Transitional Countries. Global overview of injecting drug use and HIV infection among injecting drug users. AIDS 18: 2295-2303.

2. Lorvick J, Martinez A, Gee L, Kral AH (2006) Sexual and injection risk among women who inject methamphetamine in San Francisco. J Urban Health 83: 497-505.

3. Hankins C, Alary M, Parent R, Blanchette C, Claessens C (2002) The SurvUD Working Group. Continuing HIV transmission among injection drug users in Eastern Central Canada: the SurvUDI Study, 1995 to 2000. J Acquir Immune Defic Syndr 30: 514-521.

4. Palepu A, Strathdee SA, Hogg RS, Anis AH, Rae S, et al. (1999) The social determinants of emergency department and hospital use by injection drug users in Canada. J Urban Health 76: 409-418.

5. Strathdee SA, van Ameijden EJC, Mesquita F, Wodak A, Rana S, et al. (1998) Can HIV epidemics among injection drug users be prevented? AIDS 12: 71-79.

6. Alcabes $P$, Friedland $G$ (1995) Injection drug use and human immunodeficiency virus infection. Clin Infect Dis 20: 1467-1479.

7. Remis R, Leclerc $P$ (1999) Consortium to characterize injection drug users in Canada (Montreal, Toronto and Vancouver). Final Report. University of Toronto, Toronto.

8. Bruneau J, Lamothe F, Soto J, Lachance N, Vincelette J, et al. (2001) Sexspecific determinants of HIV infection among injection drug users in Montreal. CMAJ 164: 767-773.

9. Strathdee SA, Patrick DM, Currie SL, Cornelisse PG, Rekart ML, et al. (1997) Needle exchange is not enough: lessons from the Vancouver injecting drug use study. AIDS 11: F59-65.

10. Patrick DM, Tyndall MW, Cornelisse PG, Li K Sherlock $\mathrm{CH}$, et al. (2001) Incidence of hepatitis $\mathrm{C}$ virus infection among injection drug users during an outbreak of HIV infection. CMAJ 165: 889-895.

11. Patrick DM, Buxton JA, Bigham M, Mathias RG (2000) Public health and hepatitis C. Can J Public Health 91: S18-21.

12. Lamothe F, Vincelette J, Bruneau J (1997) Prevalence, seroconversion rates and risk factors for hepatitis B core, hepatitis C and HIV antibodies among intravenous drug users (IDU) of the Saint-Luc cohort. Canadian Journal of Infectious Diseases 8: 28A.

13. Walsh J (1998) Sex, drugs and refugees. Parity 11: 6-7.

14. RRSSS (Régie Régionale de la Santé et des Services Sociaux) de Montréal- 
Citation: Bamvita JM, Zunzunegui MV, Machouf N (2013) Living Conditions and IIIness among Injecting Drug Users in Montreal. Health Care Current Reviews 1: 111. doi: 10.4172/2375-4273.1000111

Centre (1999) Organisation des services pour les personnes souffrant de problèmes de santé mentale et de toxicomanie. Rapports du Comité d'experts.

15. Mercier C, Beaucage B (1997) Toxicomanie et problèmes sévères de santé mentale: recension des écrits et état de situation pour le Québec. Comité permanent de lutteà la toxicomanie.

16. Stein MD, Anderson B (2003) Injection frequency mediates health service use among persons with a history of drug injection. Drug Alcohol Depend 70: 159168

17. Sterk CE, Theall KP, Elifson KW (2002) Health care utilization among drugusing and non-drug-using women. J Urban Health 79: 587-599.

18. Knowlton AR, Hoover DR, Chung S, Celentano DD, Vlahov D, et al. (2001) Access to medical care and service utilization among injection drug users with HIVIAIDS. Drug Alcohol Depend 64: 55-62.

19. Laine C, Hauck WW, Gourevitch MN, Cohen A, Turner BJ (2001) Regular outpatient medical and drug abuse care and subsequent hospitalization of persons who use illicit drugs. J Am Med Assoc 285: 2355-2362.

20. Crofts N, Reid G (2000) Primary Health Care among the street drug-using community in Footscray: a need analysis. The Centre for Harm Reduction. Macfarlane Burnet Centre for Medical Research. Melbourne, Australia.

21. Solomon L, Stein M, Flynn C, Schuman P, Schoenbaum E, et al. (1998) Health services use by urban women with or at risk for HIV-1 infection: The Epidemiology Research Study (HERS). J Acquir Immune Defic Syndr Hum Retrovirol 17: 253-261.

22. Selwyn PA, Budner NS, Wasserman WC, Arno PS (1993) Integrating medical care and drug abuse treatment: utilization of on-site primary care services in HIV-seropositive and -seronegative drug users in a methadone maintenance program. Public Health Rep 108: 492-500.

23. Solomon I, Frank R, Vlahov D, Astemborski J (1991) Utilization of health services in a cohort of intravenous drug users with known HIV-1 serostatus. Am J Public Health 81: 1285-1290.

24. Bourgois $P$ (1998) The moral economies of homeless heroin addicts: confronting ethnography, HIV risk, and everyday violence in San Francisco shooting encampments. Subst Use Misuse 33: 2323-2351.

25. Wodak A (1998) Medical complications of drug taking. Management of Drug Users in the Community. London.

26. Dinwiddie SH, Cottler L, Compton W, Abdallah AB (1996) Psychopathology and HIV risk behaviors among injection drug users in and out of treatment Drug Alcohol Depend 43: 1-11.

27. Rumbold G, Fry C (1998) Victorian Drug Trends 1997: findings form illicit Drug Reporting System (IDRS). NDARC Technical Report, Sydney.

28. Loxley W, Carruthers S, Bevan J (1995) In the same vein: first report of the Australian Study of HIV and Injecting Drug Use (ASHIDU).National Centre for Research into the Prevention of Drug Abuse, Curtin University of Technology, Perth.

29. Phelan JC, Link BG, Diez-Roux A, Kawachi I, Levin B (2004) Fundamental causes of social inequalities in mortality: a test of the theory. J Health Soc Behav 45: 265-285.

30. ITSS (Service de lutte contre les infections transmissibles sexuellement et par le sang) (2003) Recueil des présentations de la 18e Rencontre nationale des intervenants en prévention du VIH et des hépatites chez les UDI. Ministère de la Santé et des Services sociaux du Québec.

31. Woodburn KR, Murie JA (1996) Vascular complications of injecting drug misuse. Br J Surg 83: 1329-1334.

32. Vingoe L, Welch S, Farrel M, Strang J (1999) Heroin overdose among a treatment of sample of injecting drug misusers: accident or suicidal behaviour. Journal of Substance Use 4: 88-91.

33. Spittal PM, Hogg RS, Li K, Craib KJ, Recsky M, et al. (2006) Drastic elevations in mortality among female injection drug users in a Canadian setting. AIDS Care 18: 101-108.

34. Corneil TA, Kuyper LM, Shoveller J, Hogg RS, Li K, et al. (2006) Unstable housing, associated risk behaviour, and increased risk for HIV infection among injection drug users. Health Place 12: 79-85.
35. Roy E, Haley N, Leclerc P, Cédras L, Blais L, et al. (2003) Drug injection among street youths in Montreal: predictors of initiation. J Urban Health 80: 92-105.

36. Biernacki P, Waldord D (1981) Snowball Sampling Problems and Techniques of Chain Referral Sampling. Sociological Methods and Research 10: 141-163.

37. Estebanez PE, Russell N, Aguilar MD, Béland F, Zunzunegui MV (2000) Women, drugs and HIVIAIDS: results of a multicentreeuropean study. Int $J$ Epidemiol 29: 734-743.

38. Radloff LS (1977) The CES-D scale: a self-report depression scale for research in the general population. Applied Psychological Measurement 1: 385-401.

39. French MT, McGeary KA, Chitwood DD, McCoy CB (2000) Chronic illicit drug use, health services utilization and the cost of medical care. Soc Sci Med 50 1703-1713.

40. Fiscella K, Franks $P$, Clancy C (1998) Skepticism toward medical care and health care utilization. Med Care 36: 180-189.

41. Palepu A, Tyndall MW, Leon H, Muller J, O'Shaughnessy MV, et al. (2001) Hospital utilization and costs in a cohort of injection drug users. CMAJ 165 415-420.

42. Chitwood DD, McBride DC, Metsch LR, Comerford M, McCoy CB (1998) A comparison of the need for health care and use of health care by injectiondrug users, other chronic drug users, and nondrug users. Am Behav Sci 41 : 1107-1122.

43. Boulton M, Hart G, Fitzpatrick R (1992) The sexual behaviour of bisexual men in relation to HIV transmission. AIDS Care 4: 165-175.

44. Bruneau J, Lamothe F, Franco E, Lachance N, Desy M, et al. (1997) High rates of HIV infection among injection drug users participating in needle exchange programs in Montreal: results of a cohort study. Am J Epidemiol 146: 994-1002.

45. Petry NM (2001) Reliability of drug users' self-reported HIV risk behaviors using a brief, 11-item scale. Subst Use Misuse 36: 1731-1747.

46. De Irala J, Bigelow C, McCusker J, Hindin R, Zheng L (1996) Reliability of self-reported human immunodeficiency virus risk behaviors in a residential drug treatment population. Am J Epidemiol 143: 725-732.

47. Goldstein MF, Friedman SR, Neaigus A, Jose B, Ildefonso G, et al. (1995) Selfreports of HIV risk behavior by injecting drug users: are they reliable? Addiction 90: 1097-1104.

48. McElrath K, Chitwood DD, Griffin DK, Comerford M (1994) The consistency of self-reported HIV risk behavior among injection drug users. Am J Public Health 84: 1965-1970.

49. Gunn N, White C, Srinivasan R (1998) Primary Care as Harm Reduction for Injection Drug Users. JAMA 280: 1191-1195.

50. Cotton P (1994) "Harm reduction" approach may be middle ground. JAMA 271: 1641-1645.

51. Marlatt GA (1996) Harm reduction: come as you are. Addictive Behav 21: 779 789.

52. Hershberger SL, Wood MM, Fisher DG (2003) A cognitive-behavioral intervention to reduce HIV risk behaviors in crack and injection drug users. AIDS Behav 7: 229-243.

53. Baker A, Heather N, Wodak A, Dixon J, Holt P (1993) Evaluation of a cognitivebehavioural intervention for HIV prevention among injecting drug users. AIDS 7: 247-256.

54. Iguchi MY, Bux DA Jr, Lidz V, French JF, Baxter RC, et al. (1996) Changes in HIV risk behavior among injecting drug users: the impact of 21 versus 90 days of methadone detoxification. AIDS 10: 1719-1728.

55. O'Connor PG, Waugh ME, Carroll KM, Rounsaville BJ, Diagkogiannis IA, et al. (1995) Primary care-based ambulatory opioid detoxification: the results of a clinical trial. J Gen Intern Med 10: 255-260.

56. Bux DA, Iguchi MY, Lidz V, Baxgter RC, Platt JJ (1993) Participation in an outreach-based coupon distribution program for free methadone detoxification. Hosp Community Psychiatry 44: 1066-1072.

57. Kerr T, Wood E, Grafstein E, Ishida T, Shannon K, et al. (2005) High rates of primary care and emergency department use among injection drug users in Vancouver. J Public Health (Oxf) 27: 62-66. 